\title{
A Field Key to Identify Common Wood Decay Fungal Species on Standing Trees
}

\author{
Paolo Gonthier and Giovanni Nicolotti
}

\begin{abstract}
A field key to species is presented for the most important and widespread European wood-rotting basidiomycetes on standing trees. Sixty-four fungal taxa belonging to 36 genera and 17 families of Agaricales, Hymenochaetales, Polyporales, and Russulales are included in the key, which was mostly based on macroscopic features of the basidiomata. The key was validated in the field and allowed for easy recognition of wood decay fungi.
\end{abstract}

Key Words. Basidiocarp; basidiomata; diagnosis; field guide; simplified key.

Wood decay fungi are the primary biotic decomposers of wood. In forest ecosystems, they play an important role in carbon and nitrogen cycling and help to convert organic debris into the humus layer of the soil. They colonize downed timber and slash on the forest floor, lumber, and even wood in service. Wood decay fungi can also attack living trees, acting either as true pathogens responsible for root rots and stem cankers or as rotting agents of heartwood and sapwood. Wood decay is a major source of loss in both timber production and wood use, and, importantly for landscape trees, in parks and urban forests, it can cause a tree to be hazardous (Butin 1995).

With the exception of a few ascomycetes (e.g., Ustulina, Xylaria, Chaetomium), all the wood-attacking fungi are basidiomycetes primarily belonging to Agaricales, Hymenochaetales, Polyporales, and Russulales (Kirk et al. 2001). Dichotomous keys to species are available for lignicolous European Aphyllophorales (Breitenbach and Kränzlin 1986), an obsolete taxon that included genera from all the four previously mentioned orders, or for specific groups within Aphyllophorales. For instance, analytical keys were built for Corticiaceae s.l. (Hjortstam et al. 1978) and Polyporaceae s.l. (Bernicchia 2005). All these keys are based on the macromorphology of the basidioma and the hymenophore and, especially, on the hyphal system and on the micromorphology of septa, spores, basidia, cystidia, and other sterile organs. The assessment of the amyloidity or dextrinoidity of hyphae, spores, and hymenial organs through microscopic observations of the staining reactions to Melzer's solution is also needed for determination. Thus, regular identification of wood decay fungi requires specialized mycologists and equipped laboratories, and the identification can be rarely achieved in the field.
Identification keys to polypores are available on the Internet (Ryvarden 1998) or in computerized format (Adaskaveg et al. 1994). Furthermore, descriptions of wood-rotting fungi on standing trees, often equipped with simplified keys, are provided with practical field guides to urban tree pathology or to tree hazard assessment (Strouts and Winter 1994; Lonsdale 1999; Intini et al. 2000). These simplified keys, however, are based also on ecological characters such as host preference, which is questionable considering that only few wood decay fungi display high levels of host specialization (Rayner and Boddy 1988; Nicolotti et al. 2004a). Moreover, simplified keys only go to the genera level or they allow for the discrimination of groups of genera (Lonsdale 1999; Alaux 2006). There is good reason, especially in tree hazard assessment, to make accurate identification at the species level of the fungi concerned, because the behavior of wood-rotting fungi in terms of aggressiveness and ability to overcome host defenses can be highly variable among different species within genera (Schwarze and Baum 2000). This could aid in prognosis if the typical patterns of spread within the tree and the effects on wood strength of fungal species are known and, therefore, to some extent predictable (Lonsdale 1999).

A field key to species, based on the macroscopic features of basidiomata, is provided for the identification of the most important and widespread European wood-rotting basidiomycetes on standing trees.

\section{MATERIALS AND METHODS}

European wood-rotting species of basidiomycetes were selected to be included in the key based on their frequency of occurrence on standing trees as determined from previously published information (Breitenbach and Kränzlin 1986; Nicolotti et al. 2004a; Bernicchia 2005). In addition to widespread 
species, infrequent species were included in the key either as important tree pathogens or as aggressive decay agents on standing trees (Strouts and Winter 1994; Lonsdale 1999; Nicolotti 2004b).

\section{Selection of Characters and Key Construction}

Only characters resulting from macroscopic observations of the basidiomata, of their longitudinally cross-sections, or of the color of spore print were retained as good characters for taxa discrimination in this work. Selected characters were: the absence or the presence and the point of insertion (i.e., lateral, central) of the stalk; the general shape of the basidiomata (i.e., resupinate, applanate, ungulate, and so on); the type of hymenophore (i.e., smooth, lamellate, with pores); the color of the hymenophore and its reaction when bruised; pore shape and size; the color, the consistency, and the general features of the sterile surface, including the presence of hairs or other appendages and its reaction to fire exposure; the color and the odor of the context, and the presence of differently colored lines or layers within the context as assessed through observations of longitudinally cross-sections of the basidiomata; and the color of the spore print.

All these characters were used to describe each of the previously selected wood-rotting basidiomycetes. Data collection was performed by comparing the descriptions of decay fungi available from the literature (Breitenbach and Kränzlin 1986; Breitenbach 1991, 1995; Lonsdale 1999; Intini et al. 2000; Bernicchia 2005) and by accurate observations of fresh specimens of the Herbarium of the Department of Exploitation and Protection of the Agricultural and Forestry Resources-University of Torino (Torino, Italy), previously identified with the aid of analytical keys (Breitenbach and Kränzlin 1986; Breitenbach 1991, 1995, 2005).

\section{Key Validation}

Basidiomata were identified in the field with the aid of the key included in the present paper singly by eight MSc students of Forestry and Environmental Sciences (University of Torino). After field identification, basidiomata were collected, transferred to the laboratory, and determined with analytical keys by mycologists as described previously.

The validation of the key was assumed to be accomplished if the number of basidiomata successfully identified with the field key on the total number of basidiomata collected, overall and for each taxon, was over 0.7 (validation cutoff ratio).

\section{RESULTS}

Sixty-four fungal taxa were included in the key (Appendix). Taxa, which are listed in Table 1, belonged to the following families: Bolbitiaceae, Bondarzewiaceae, Coniophoraceae, Fistulinaceae, Fomitopsidaceae, Ganodermataceae, Gloeophyllaceae, Hapalopilaceae, Hymenochaetaceae, Marasmiaceae,
Meripilaceae, Meruliaceae, Pleurotaceae, Polyporaceae, Schizophyllaceae, Stereaceae, and Strophariaceae.

The key was built to determine wood-rotting basidiomycetes at the species level. Armillaria mellea complex and Heterobasidion annosum complex represent two exceptions and are referred in the key as Armillaria spp. and Heterobasidion spp., respectively.

Basidiomata collected and identified in the laboratory for key validation belonged to 55 of the 64 taxa included in the field key. Two to three basidiomata were found for each fungal taxon, resulting in a total of 992 case studies (124 basidiomata $\times$ eight identifiers). Overall, the determination with the field identification key matched that obtained with the analytical key in 893 case studies (validation ratio $=$ 0.900). With the exception of Ganoderma adspersum, all the taxa resulted in validation ratios higher or equal to 0.750 (Table 1).

\section{DISCUSSION}

The most common wood-rotting species of basidiomycetes occurring on standing trees in central and southern Europe were considered for key construction, irrespective of their ecological behavior. In addition to strict saprobes, the species list includes root pathogens (e.g., Armillaria spp., Heterobasidion spp., Inonotus dryadeus, Ganoderma adspersum), stem pathogens (e.g., Chondrostereum purpureum, Phellinus pini, Inonotus hispidus), and fungi associated with the root system or the bole and known for their negative interactions with the tree stability either in the forest (i.e., Climacocystis borealis) (Rigling et al. 2005) or in urban landscape (i.e., Perenniporia fraxinea) (Nicolotti 2004b).

Taxonomic keys are generally built to discriminate taxa within systematic groups. This is true also for wood decay fungi. Keys to Corticiaceae s.1. (Hjortstam et al. 1978), Polyporaceae s.l. (Bernicchia 2005), and even Aphyllophorales (Breitenbach and Kränzlin 1986), although very analytical, fail to some extent in that, in each of them, one or more groups of decay fungi are lacking, and consequently, none can be used as a unique tool for the identification of decay fungi occurring in standing trees. Members of 17 families of all the four orders of wood decay basidiomycetes, including Agaricales, are considered in our field key. In general terms, this represents a great advantage with respect to other published keys, because it would allow the determination to nonmycologists that could ignore the differences of basidiomata at the family level, which is rarely reported in traditional keys.

The key is validated, because the ratio of basidiomata successfully identified on the total number of basidiomata included in the validation process was greatly higher than the adopted validation cutoff ratio. Ganoderma adspersum was characterized by the lowest validation ratio (0.708) and was mostly confused with $G$. applanatum. Very low divergences 


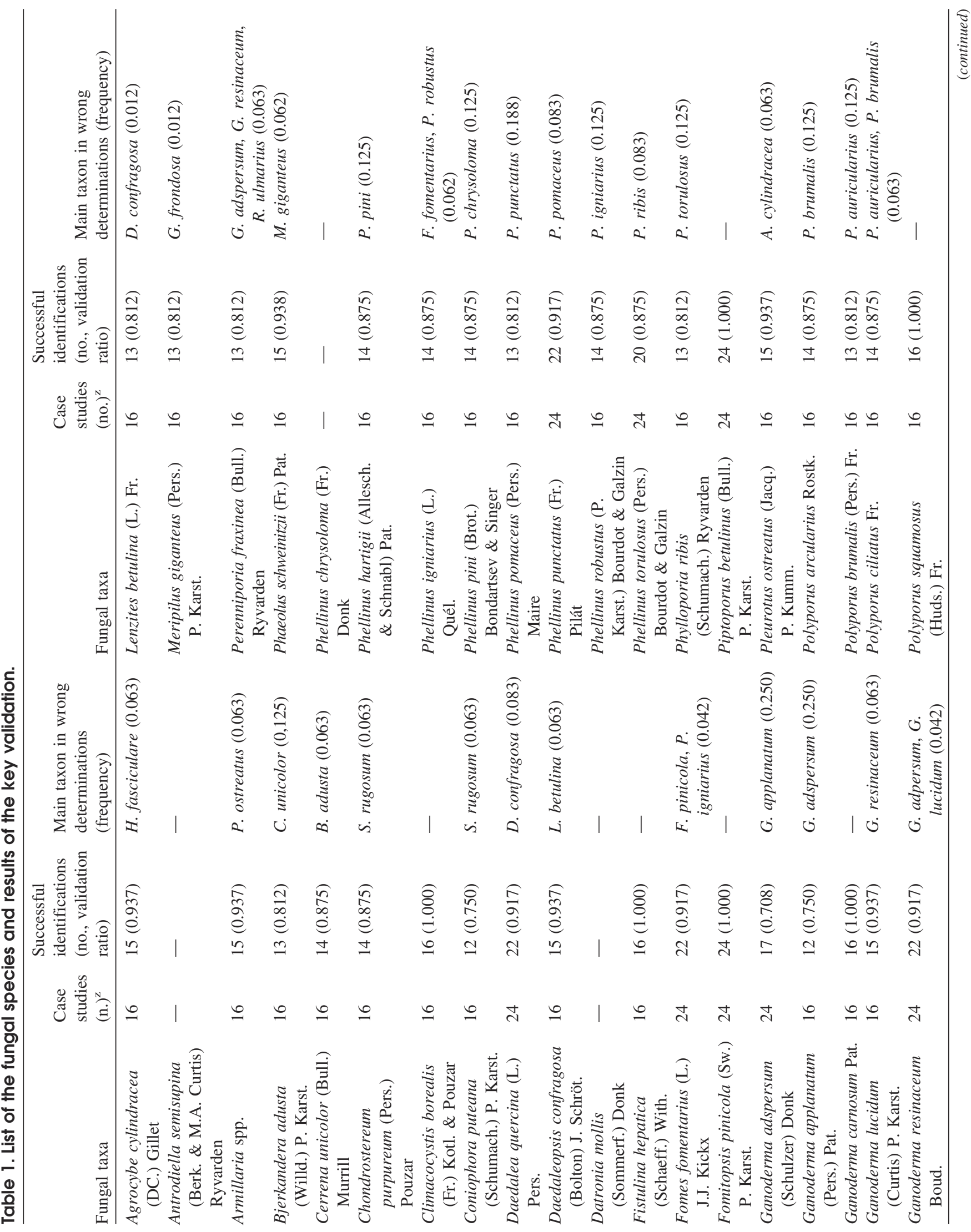




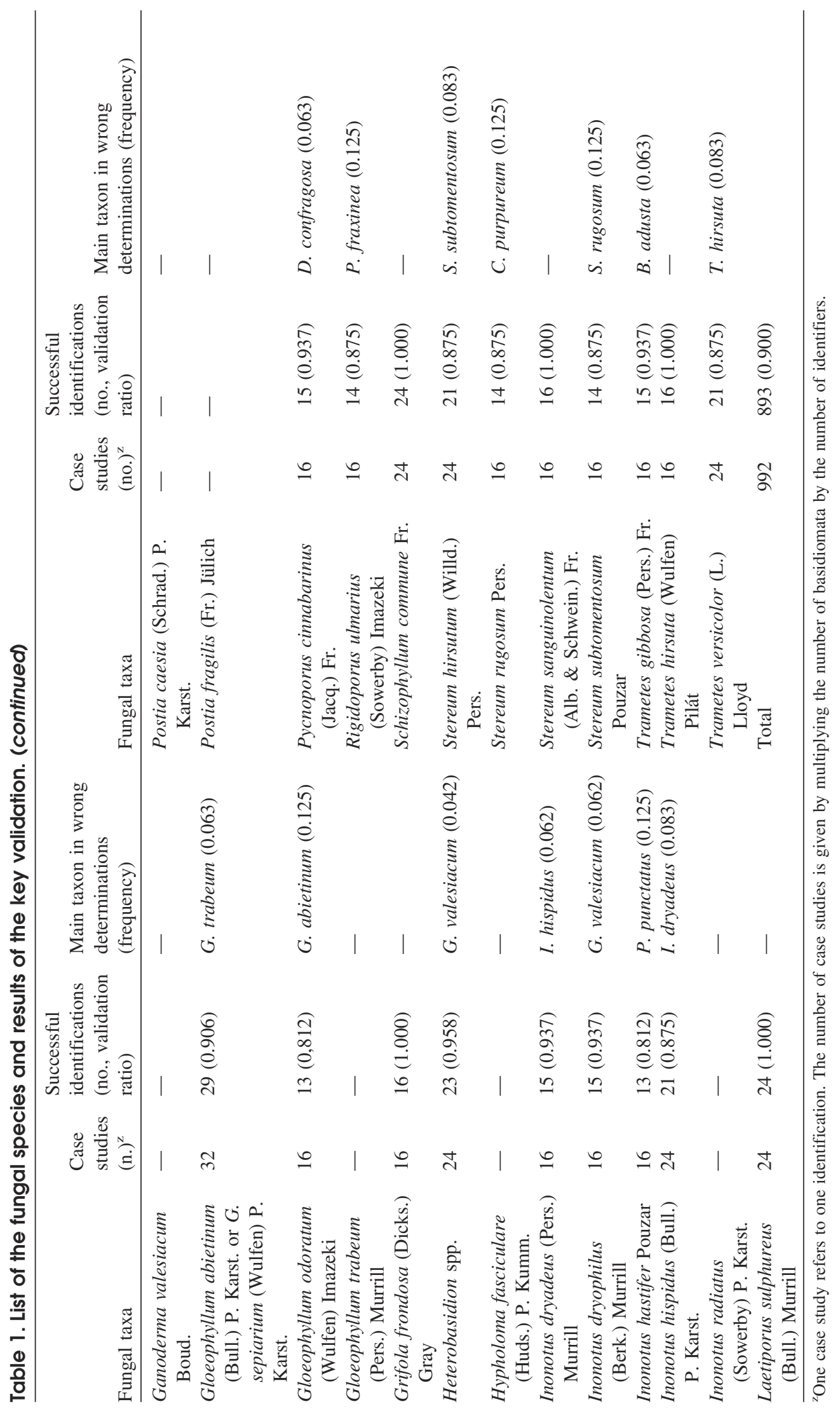


between European specimens of these two species, based both on morphological and molecular traits, were previously reported (Breitenbach and Kränzlin 1986; Hong and Jung 2004; Guglielmo 2005). However, a reasonable confusion between these two species could be acceptable in tree hazard assessment, because the decay they cause seems to affect in a similar manner the tree stability (Lonsdale 1999).

Thus, a reliable identification of common wood decay fungi can be easily achieved through this key without needing the use of potassium hydroxide or other reagents, which are often required by other keys. Another advantage is that the identification process is rapid, unless a spore print analysis is needed, like for the discrimination between basidiomata of Armillaria and basidiomata of other lamellate and centrally stipitate species. However, the diagnosis of Armillaria could be easier and immediately achieved when the typical Armillaria rhizomorphs and/or mycelium are found.

Species descriptions are not included in this article, and to accomplish an accurate determination, the user should refer to descriptions contained in monographs. We suggest the user check the description of not only the species determined, but also of the species, inferable from Table 1, that could have been confused with it.

The key provided in this article is principally addressed to forest pathologists and arborists with a mycological background while performing field diagnosis or tree hazard assessment. However, its range of application is broader. For instance, it could be useful for didactic purposes and could be of aid to ecological research conducted in the parks or in the forest environments.

Acknowledgments. We are grateful to the eight anonymous MSc students involved in the key validation process.

\section{LITERATURE CITED}

Adaskaveg, J.E., M.R. Dunlap, R.L. Gilbertson, and E.E. Butler. 1994. Development of a computerized, synoptic key for polyporoid, wood-rotting fungi of North America. Mycotaxon 52:289-302.

Alaux, C. 2006. Champignons lignivores: Comment identifier les principaux genres. Phytoma 594:33-36.

Bernicchia, A. 2005. Polyporaceae s.l. Candusso, Alassio, Italy. $808 \mathrm{pp}$.

Breitenbach, J. 1991. Champignons de Suisse, Bolets et Champignons à Lames, Tome III, Mykologia, Luzern, Switzerland. 364 pp.

___ 1995. Champignons de Suisse, Champignons à Lames, Tome IV. Mykologia, Luzern, Switzerland. 371 pp.

Breitenbach, J., and F. Kränzlin. 1986. Champignons de Suisse, Champignons sans Lames, Tome II. Mykologia, Luzern, Switzerland. 412 pp.
Butin, H. 1995. Tree Diseases and Disorders. Oxford University Press, New York, NY. 252 pp.

Guglielmo, F. 2005. A molecular approach for the detection and early identification of wood rotting fungi as useful tool in tree stability assessment. Ph.D. Thesis, University of Florence, Florence, Italy. 131 pp.

Hjortstam, K., K.H. Larsson, and L. Ryvarden. 1978. The Corticiaceae of North Europe. Vol. 1. Fungiflora, Oslo, Norway. 60 pp.

Hong, S.G., and H.S. Jung. 2004. Phylogenetic analysis of Ganoderma based on nearly complete mitochondrial small-subunit ribosomal DNA sequences. Mycologia 96: 742-755.

Intini, M., A. Panconesi, and C. Parrini. 2000. Malattie Delle Alberature in Ambiente Urbano. CNR-IPAF, Florence, Italy. 215 pp.

Kirk, P.M., P.F. Cannon, J.C. David, and J. Stalpers. 2001. Ainsworth and Bisby's Dictionary of the Fungi. 9th ed. CAB International, Wallingford, UK. 655 pp.

Lonsdale, D. 1999. Principles of Tree Hazard Assessment and Management. Forestry Commission, London, UK. 388 pp.

Nicolotti, G., D. Pecollo, and P. Gonthier. 2004a. Ecologia e grado di preferenza d'ospite dei funghi agenti di carie, I parte. Acer 1/04:47-51.

- 2004b. Ecologia e grado di preferenza d'ospite dei funghi agenti di carie, II parte. Acer 2/04:59-67.

Rayner, A.D.M., and L. Boddy. 1988. Fungal Decomposition of Wood, Its Biology and Ecology. John Wiley \& Sons Ltd., Chichester, UK. 587 pp.

Rigling, D., H. Blauenstein, and M. Dobbertin. 2005. Incidence of root and butt rot in storm-damaged versus nondamaged Norway spruce. Proceedings of the 11th International Conference on Roots, Root and Butt Rots of Forest Trees, Poznan-Bialowieza, Poland, 16-22 August 2004. In M. Małgorzata and P. Łakomy (Eds.). The August Cieszkowski Agricultural University Poznań, Poznań, Poland.

Ryvarden, L. 1998. Norske Poresopper. Fungiflora, Oslo, Norway. http://biologi.uio.no/bot/ascomycetes/NorskePores_ key.htm (accessed 5/17/2007).

Schwarze, F.W.M.R., and S. Baum. 2000. Mechanisms of reaction zone penetration by decay fungi in wood of beech (Fagus sylvatica). The New Phytologist 146:129-140.

Strouts, R.G., and T.G. Winter. 1994. Diagnosis of Ill-health in Trees. Forestry Commission, London, UK. 308 pp.

Paolo Gonthier

Assistant Professor

University of Torino

Department of Exploitation and Protection of the Agricultural and Forestry Resources-Plant Pathology

via Leonardo da Vinci 44

I-10095 Grugliasco (TO), Italy 


\author{
Giovanni Nicolotti (corresponding author) \\ Associate Professor \\ University of Torino \\ Department of Exploitation and Protection of the \\ Agricultural and Forestry Resources-Plant Pathology \\ via Leonardo da Vinci 44 \\ I-10095 Grugliasco (TO), Italy \\ giovanni.nicolotti@unito.it
}

Résumé. Une clé pratique des espèces est présentée pour les basidiomycètes les plus importants et les plus répandus en Europe qui causent de la pourriture du bois. Soixante-quatre taxons appartenant à 36 genres et 17 familles d'agarics, d'hyménochètes, de polypores et de russules sont inclus dans cette clé qui est basée essentiellement sur les éléments macroscopiques des basidiomycètes. La clé a été testée sur le terrain et permet une identification facile des champignons de carie du bois.

Zusammenfassung. Hier wird ein Feldschlüssel für die wichtigsten und weitverbreiteten europäischen holzzerstörenden Basidiomyceten an stehendem Holz vorgestellt. 64 Pilzarten in 36 Gattungen und 17 Familien der Agaricales, Hymenochaetales, Polyporales, und Russulales sind in dem Schlüssel aufgeführt, der hauptsächlich auf macroskopischen Eigenschaften der Basidiomyceten beruht. Der Schlüssel wurde praxisgestestet und erlaubt eine einfache Erkennung von holzzerstörenden Pilzen.

Resumen. Se presenta una clave de campo para las especies de los basidiomicetos más importantes y dispersos descomponedores de madera en rodales de árboles. Sesenta y cuatro taxa pertenecientes a 36 géneros y 17 familias de Agaricales, Hymenochaetales, Polyporales y Russulales son incluidos en la clave, que se basó principalmente en características del basidiomata. La clave fue validada en el campo para reconocimiento fácil del hongo descomponedor de la madera.

\section{Appendix. Field key to wood-rotting fungal species on standing trees ${ }^{2}$.}

1. basidioma stipitate

1.1. stipe distinct to rudimentary, resulting in laterally stipitate basidioma

1.1.1. hymenophore poroid with small round pores

1.1.1.1. sterile surface with a varnished and concentrically zonate reddish crust

1.1.1.1.1. usually on conifers Ganoderma carnosum

[1.6-8]

1.1.1.1.2. usually on broadleaves Ganoderma lucidum

${ }^{z}$ Within parentheses, the basidioma's size, in (centimeters) and [inches]. Asterisks $(*, * *)$ refer to the total size of multiple basidiomata and to the pileus reflection length of effused-reflexed basidiomata, respectively.
$(3-10)$

[1.2-3.2]

1.1.1.2. sterile surface glossy, but not concentrically zonate

1.1.1.2.1. upper surface covered with a glabrous and resinoid reddish crust Ganoderma resinaceum

(15-50)

[6-20]

1.1.1.2.2. fleshy and juicy basidioma with a hispid sterile surface Fistulina hepatica

(7-20)

[2.8-8]

1.1.2. $(\downarrow)$ hymenophore poroid with pores irregular to elongated Polyporus squamosus

$(<50-60)$

$[<20-24]$

1.1.3. hymenophore lamellate Pleurotus ostreatus

(4-20)

[1.6-8]

1.2. centrally stipitate basidioma

1.2.1. stipe with a ring (annulus present); hymenophore lamellate

1.2.1.1. spore print light; pileus umbonate; sterile surface with or without squamules

Armillaria spp.

(3-13)

[1.2-5.2]

1.2.1.2. spore print brown

1.2.1.2.1. lamellae whitish at first, then brownish; pileus not umbonate

Agrocybe cylindracea

(3-12)

[1.2-4.8]

1.2.1.2.2. lamellae sulphur yellow at first, then greenish; broad umbo sometimes present on the pileus

Hypholoma fasciculare

(2-6)

[0.8-2.4]

1.2.2. stipe without ring (annulus lacking); hymenophore poroid to lamellate

1.2.2.1. hymenophore poroid with small round pores

Polyporus ciliatus

$(<6-8)$

[<2.4-3.2]

1.2.2.2. $(\downarrow)$ hymenophore poroid with pores hexagonal or angular to elongated

1.2.2.2.1. sterile surface with small squamules

Polyporus arcularius

$(<3-5)$

$[<1.2-2]$

1.2.2.2.2. sterile surface without squamule

Polyporus brumalis

$(<5-8)$

$[<2-20]$ 
1.2.2.3. hymenophore lamellate Hypholoma fasciculare

(2-6)

[0.8-2.4]

2. $(\downarrow)$ basidiomata with a common base, with stipe repeatedly branched, or imbricate, rarely pseudostipitate; hymenophore poroid

2.1. upper surface yellow to pink, yellowish to orange; hymenophore sulphur yellow; unpleasant odor Laetiporus sulphureus

(10-30)

[4-12]

2.2. above characters not combined

2.2.1. whitish stipe thick at the base; sterile surface gray to brown

Grifola frondosa

$(<40-50 * / 5-10)$

$[<16-20 * / 2-4]$

2.2.2. ( $\downarrow)$ stipe short, stout, originating from a common base; sterile surface brown to reddish brown

Meripilus giganteus

$(<100 * / 10-30)$

$[<40 * / 4-12]$

2.2.3. stipe (pseudostipe) stout and covered with decurrent pores; sterile surface brown, rough, and tomentose

Phaeolus schweinitzii

$(<30)$

$[<12]$

3. basidioma sessile or resupinate (without a stalk)

3.1. hymenophore smooth to irregularly undulate or warty; basidioma resupinate to effused-reflexed

3.1.1. thin tough flat brown plate, usually with whitish and sometimes frayed margin

Coniophora puteana

(cm or $\mathrm{dm}$ )

[in or $\mathrm{ft}$ ]

3.1.2. basidioma effused-reflexed, resupinate exclusively when it growths on undersides of branches and logs

3.1.2.1. hymenophore turning blood red when bruised

3.1.2.1.1. on conifers Stereum sanguinolentum

$(<15 /<1.5 * *)$

$\left[<6 /<0.6^{* *}\right]$

3.1.2.1.2. on broadleaves Stereum rugosum

$\left(<15 / 2-3^{* *}\right)$

$[<6 /<0.8-1.2 * *]$

3.1.2.2. hymenophore turning in any color other than red or which do not stain when bruised

3.1.2.2.1. hymenophore gray-yellowish, turning yellow when bruised

Stereum subtomentosum

(3-7)

[1.2-2.8]

3.1.2.2.2. hymenophore that do not stain at all when bruised
3.1.2.2.2. hymenophore violet or lilac to brown; a black line is visible in cross-section in the context close to the tomentum

Chondrostereum purpureum

(cm or $\mathrm{dm} / 2-4 * *)$

[in or $\mathrm{ft} / 0.8-1.6 * *$ ]

3.1.2.2.2.2. hymenophore grayish to yellowish; a yellow line is visible in cross-section in the context close to the tomenum

Stereum hirsutum

(cm or $\mathrm{dm} / 0.5-3 * *)$

[in or $\mathrm{ft} / 0.2-1.2 * *$ ]

3.2. $(\downarrow)$ hymenophore with pores elongated, sinuous, daedaleoid to lamellate; basidioma resupinate, effusedreflexed or pileate

3.2.1. pileus shell-shaped; sterile surface hirsute, hispid, grayish; pinkish lamellate hymenophore

Schizophyllum commune

$(1-4)$

[0.4-1.6]

3.2.2. above characters not combined

3.2.2.1. on conifers, including wood in service

3.2.2.1.1. basidioma tough, corky or woody

3.2.2.1.1.1. hymenophore lamellate with brown lamellae

Gloeophyllum sepiarium

Gloeophyllum abietinum

(2-5)

[0.8-2]

3.2.2.1.1.2. hymenophore poroid with pores round to elongated

3.2.2.1.1.2.1. basidioma with a strong scent of anise

Gloeophyllum odoratum

(5-20)

[2-8]

3.2.2.1.1.2.2. basidioma without scent of anise

Phellinus pini

(15-20)

[6-8]

Gloeophyllum trabeum (rare)

(3-8)

[1.2-3.2]

3.2.2.1.2. basidioma fleshy; hymenophore poroid with pores angular

Phaeolus schweinitzii

$(<30)$

$[<12]$

3.2.2.2. on broadleaves

3.2.2.2.1. basidioma fleshy; hymenophore poroid with pores angular

Phaeolus schweinitzii

$(<30)$

$[<12]$

3.2.2.2.2. basidioma tough, corky or woody 
3.2.2.2.2.1. hymenophore poroid with pores sinuous to daedaleoid

3.2.2.2.2.1.1. pileus and hymenophore cream, grayish or yellow-brownish; on Quercus species

\section{Daedalea quercina}

$(<15-20)$

$[<6-8]$

3.2.2.2.2.1.2. ( $\downarrow$ ) sterile surface hirsute, brown-gray, or green when epiphytic algae are present; hymenophore grayish that do not stain when bruised; context duplex, the two layers are separated by a thin, dark zone

Cerrena unicolor

$\left(10-15 / 0.5^{* *}\right)$

$[4-6 / 0.2 * *]$

3.2.2.2.2.1.3. ( $\downarrow$ ) sterile surface tomentose, cream to brown, usually azonate; hymenophore gray, darker when bruised; tube layer and context are separated by a thin but distinct dark layer

Bjerkandera adusta

(2-6)

[0.8-2.4]

3.2.2.2.2.1.4. ( $\downarrow$ ) sterile surface brown to blackish, concentrically zonate; hymenophore ochraceous to brown, darker when bruised; black layer present in the context close to the tomentum

Datronia mollis

$\left(\mathrm{cm}\right.$ or $\left.\mathrm{dm} /<1.5^{* *}\right)$

[in or $\mathrm{ft} /<0.6^{* *}$ ]

3.2.2.2.2.1.5. $(\downarrow)$ basidioma cream to yellowish brown; on Quercus and Betula

Lenzites betulina

$(<8-10)$

$[<3.2-4]$

3.2.2.2.2.1.6. sterile surface tomentose, cream to ochraceous, green when epiphytic algae are present; hymenophore cream; margin obtuse

Trametes gibbosa

(10-15)

[4-6]

3.2.2.2.2.2. ( $\downarrow$ ) hymenophore lamellate

3.2.2.2.2.2.1. upper surface brown to reddish-brown, glabrous

Daedaleopsis confragosa

$(5-15)$

[2-6]

3.2.2.2.2.2.2. upper surface cream to yellowish brown, hirsute, tomentose

Lenzites betulina

$(<8-10)$

$[<3.2-4]$

3.2.2.2.2.3. hymenophore poroid with pores round to elongated
3.2.2.2.2.3.1. sterile surface brown to blackish, concentrically zonate; hymenophore ochraceous to brown, darker when bruised; context brown, with a black layer close to the tomentum

Datronia mollis

$\left(\mathrm{cm}\right.$ or $\left.\mathrm{dm} /<1.5^{* *}\right)$

[in or $\mathrm{ft} /<0.6^{* *}$ ]

3.2.2.2.2.3.2. ( $\downarrow$ ) context reddish brown to cinnamon brown

Gloeophyllum trabeum (rare)

(3-8)

[1.2-3.2]

3.2.2.2.2.3.3. $(\downarrow)$ sterile surface hirsute, brown-gray, or green when epiphytic algae are present; hymenophore greyish that do not stain when bruised; context cream, duplex, with the two layers separated by a thin, dark zone

Cerrena unicolor

$\left(10-15 / 0.5^{* *}\right)$

[4-6/0.2**]

3.2.2.2.2.3.4. ( $\downarrow$ ) sterile surface tomentose, cream to brown, usually azonate; hymenophore gray, darker when bruised; context whitish-grayish; tube layer and context are separated by a thin but distinct dark layer

Bjerkandera adusta

(2-6)

[0.8-2.4]

3.2.2.2.2.3.5. sterile surface tomentose, cream to ochraceous, green when epiphytic algae are present; hymenophore cream; context white; margin obtuse

Trametes gibbosa

$(10-15)$

[4-6]

3.3. hymenophore poroid with pores round or almost round; basidioma resupinate to pileate

3.3.1. hymenophore white to cream

3.3.1.1. pileate, on conifers

3.3.1.1.1. sterile surface concentrically sulcate, gray, brown, blackish, or purple red, with a resinous layer, becoming sticky when exposed to fire; margin obtuse

Fomitopsis pinicola

$(<30-40)$

$[<12-16]$

3.3.1.1.2. ( $\downarrow$ ) basidioma effused-reflexed or applanate; sterile surface tobacco brown; margin acute

Heterobasidion spp.

(3-35)

[1.2-14]

3.3.1.1.3. $(\downarrow)$ sterile surface with a varnished reddish crust; margin acute

Ganoderma carnosum

(4-20)

[1.6-8] 


\section{Ganoderma valesiacum}

(6-10)

[2.4-4]

3.3.1.1.4. $(\downarrow)$ sterile surface white to brown, delicately tomentose; basidioma turning reddish brown when bruised

Postia fragilis

(cm or $\mathrm{dm})$

[in or $\mathrm{ft}$ ]

3.3.1.1.5. $(\downarrow)$ sterile surface grayish to blue, slightly hirsute; basidioma turning darker blue when touched or bruised

Postia caesia

(2-4)

[0.8-1.6]

3.3.1.1.6. sterile surface whitish, hirsute

Climacocystis borealis

$(<10)$

$[<4]$

3.3.1.2. $(\downarrow)$ pileate or effused-reflexed, on broadleaves

3.3.1.2.1. upper surface tobacco brown or covered with a varnished reddish crust

3.3.1.2.1.1. sterile surface tobacco brown

3.3.1.2.1.1.1. basidioma applanate; upper surface concentrically zonate and covered with a hard, dull cuticle; red-brown powder, representing spore mass, is often present on the top of basidioma and its surroundings; hymenophore darker when touched, often showing galls produced by insects as warty outgrowths; thin context zones separate the tube's layers

\section{Ganoderma applanatum}

(40-60)

[16-24]

3.3.1.2.1.1.2. basidioma applanate; upper surface tuberculate, sulcate, zonate, covered with a hard crust; hymenophore darker when touched; tube layers not separated by context zones

Ganoderma adspersum

$(40-50)$

[16-20]

3.3.1.2.1.2. sterile surface covered with a varnished reddish crust or dull cuticle

\section{Ganoderma resinaceum}

$(15-50)$

[6-20]

3.3.1.2.2. $(\downarrow)$ upper surface slightly hirsute grayish to blue, darker when touched; basidioma applanate to effusedreflexed

Postia caesia

$(2-4)$

[0.8-1.6]

3.3.1.2.3. $(\downarrow)$ upper surface velvety, ochraceous to cream; basidioma applanate to effused-reflexed (quite rare)
Antrodiella semisupina

$\left(0.5-2 / 0.5-1.5^{* *}\right)$

$\left[0.2-0.8 / 0.2-0.6^{* *}\right]$

3.3.1.2.4. $(\downarrow)$ upper surface cream to brown, papiraceous; on Betula

Piptoporus betulinus

$(<20-25)$

$[<8-10]$

3.3.1.2.5. $(\downarrow)$ upper surface grayish to brownish, concentrically zonate; context separated from the tomentum by a thin, black layer

3.3.1.2.5.1. sterile surface hirsute

Trametes hirsuta

$(<10)$

$[<4]$

3.3.1.2.5.2. sterile surface velvety; often green or blue when epiphytic algae are present

Trametes versicolor

$(<10)$

$[<4]$

3.3.1.2.6. upper surface cream ochraceous with grayish nuances, sulcate; margin thick; hymenophore with a pinkish shade

Rigidoporus ulmarius

$(<20-30)$

$[<8-12]$

3.3.1.3. resupinate, on conifers or broadleaves

3.3.1.3.1. hymenophore turning reddish or brownish when touched or bruised; on conifers

Postia fragilis

(cm or $\mathrm{dm}$ )

[in or $\mathrm{ft}$ ]

3.3.1.3.2. hymenophore that do not stain when bruised

3.3.1.3.2.1. tube layer cartilaginous, often moderately thick (approximately 2 to $3 \mathrm{~mm} / 0.08$ to $0.12 \mathrm{in}$ ); very faint odor; on broadleaves, rarely on conifers

Antrodiella semisupina

$\left(0.5-2 / 0.5-1.5^{* *}\right)$

$\left[0.2-0.8 / 0.2-0.6^{* *}\right]$

3.3.1.3.2.2. $(\downarrow)$ tube layer not cartilaginous, 1 to $6 \mathrm{~mm}$ (0.04 to 0.24 in) thick; faint smell of anise; on broadleaves, rarely on conifers

Trametes hirsuta

$(<10)$

$[<4]$

3.3.1.3.2.3. tube layer not cartilaginous, 3 to $6 \mathrm{~mm}$ (0.12 to $0.24)$ thick; strong smell of mushroom; on conifers, rarely on broadleaves

Heterobasidion spp.

(3-35)

[1.2-14]

3.3.2. ( $\downarrow$ ) hymenophore greyish

3.3.2.1. basidioma pileate 
3.3.2.1.1. hymenophore turning darker when touched or bruised

3.3.2.1.1.1. pileus ungulate; sterile surface gray to brown, glabrous, with a thick and hard crust

Fomes fomentarius

$(<30-40)$

$[<12-16]$

3.3.2.1.1.2. pileus variously shaped, but not ungulate

3.3.2.1.1.2.1. basidioma broadly attached; sterile surface glabrous, tuberculate, gray ochraceous to black with an evident crust; hymenophore with pinkish nuances

Perenniporia fraxinea

(30-40)

[12-16]

3.3.2.1.1.2.2. ( $\downarrow$ ) sterile surface tomentose, cream to brown; context whitish to gray; tube layer and context separated by a thin but distinct dark line

Bjerkandera adusta

(2-6)

[0.8-2.4]

3.3.2.1.1.2.3. sterile surface tomentose, nodular, tawny brown to yellow brown; margin thin, yellowish; hymenophore with brown nuances and covered with a silver-grayish pruine

Inonotus radiatus

$(5-10)$

[2-4]

3.3.2.1.2. hymenophore that do not stain when touched or bruised

3.3.2.1.2.1. pileus ungulate; sterile surface gray to brown, glabrous, with a thick and hard crust

Fomes fomentarius

$(<30-40)$

$[<12-16]$

3.3.2.1.2.2. pileus applanate to effused-reflexed; sterile surface hirsute, brown-gray, or green when epiphytic algae are present; context duplex, the two layers are separated by a thin, dark zone

Cerrena unicolor

$\left(10-15 / 0.5^{* *}\right)$

[4-6/0.2**]

3.3.2.2. basidioma resupinate

3.3.2.2.1. hymenophore turning darker when touched or bruised

Bjerkandera adusta

(2-6)

[0.8-2.4]

3.3.2.2.2. hymenophore that do not stain when touched or bruised

Cerrena unicolor

$(10-15 / 0.5 * *)$

$[4-6 / 0.2 * *]$
3.3.3. ( $\downarrow$ ) hymenophore, margin, and sterile surface orange red to cinnabar red

Pycnoporus cinnabarinus

$(<10-15)$

$[<4-6]$

3.3.4. $(\downarrow)$ hymenophore pinkish to pinkish brown; upper surface cream ochraceous with grayish nuances, sulcate; margin thick

Rigidoporus ulmarius

$(<20-30)$

$[<8-12]$

3.3.5. hymenophore cinnamon brown to tobacco brown

3.3.5.1. usually on conifers

3.3.5.1.1. basidioma pileate, with pileus distinct to rudimentary

3.3.5.1.1.1. sterile surface rough, concentrically zonate, sometimes rimose, sulcate, brown; generally on Abies

Phellinus hartigii

$(<30)$

$[<12]$

3.3.5.1.1.2. $(\downarrow)$ sterile surface sulcate, zonated, radially rimose, reddish brown; absence of a black line close to the tomentum; generally on Pinus

Phellinus pini

$(15-20)$

[6-8]

3.3.5.1.1.3. sterile surface hirsute, tomentose, zonate, sulcate, brown; thin black line present close to the tomentum; generally on Picea and Pinus

Phellinus chrysoloma

(cm or $\mathrm{dm}$ )

[in or $\mathrm{ft}$ ]

3.3.5.1.2. basidioma resupinate

3.3.5.1.2.1. hymenophore with small round pores; usually on Abies

Phellinus hartigii

$(<30)$

$[<12]$

3.3.5.1.2.2. hymenophore with pores angular to sinuous; usually on Picea or Pinus

Phellinus chrysoloma

(cm or $\mathrm{dm}$ )

[in or $\mathrm{ft}$ ]

3.3.5.2. usually on broadleaves

3.3.5.2.1. basidioma ungulate

3.3.5.2.1.1. basidioma woody; sterile surface nodulous, zonate, sulcate, reddish brown; margin wide, round, yellow brown

Phellinus robustus

(10-20)

[4-8]

3.3.5.2.1.2. $(\downarrow)$ basidioma woody; sterile surface crusty, sulcate, gray to gray brown; margin thick, gray 


\section{Phellinus ignarius}

$(10-15)$

[4-6]

3.3.5.2.1.3. $(\downarrow)$ sterile surface sulcate, rimose, brown, grayish or blackish

Phellinus pomaceus

(cm or $\mathrm{dm}$ )

[in or $\mathrm{ft}$ ]

3.3.5.2.1.4. sterile surface velvety or glabrous, zonated, rusty brown to amber brown; margin thick, and clearer than upper surface

Inonotus dryophilus

$(10-15)$

[4-6]

3.3.5.2.2. $(\downarrow)$ basidioma applanate

3.3.5.2.2.1. basidioma corky, woody or suberous

3.3.5.2.2.1.1. sterile surface zonated, sulcated, brown, tomentose

3.3.5.2.2.1.1.1. margin wide, obtuse, undulate, cinnamon brown

Phellinus torulosus

$(<40-50)$

$[<16-20]$

3.3.5.2.2.1.1.2. margin thin, undulate, brown

Phylloporia ribis

(15-20)

[6-8]

3.3.5.2.2.1.2. sterile surface azonated, sulcated, brown to blackish, tomentose; hymenophore brown to yellow brown, sometimes with brownish droplets

Inonotus dryadeus

$(30-50)$

[12-20]

3.3.5.2.2.2. basidioma spongy or fleshy

3.3.5.2.2.2.1. sterile surface tomentose but not hirsute, azonated, sulcated, brown to blackish; hymenophore brown to yellow brown, sometimes with brownish droplets

Inonotus dryadeus

(30-50)

[12-20]

3.3.5.2.2.2.2. sterile surface hispid, hirsute, reddish brown to dark brown, to black; hymenophore yellow to tawny brown, sometimes with transparent droplets

Inonotus hispidus

(15-30)

[6-12]

3.3.5.2.3. basidioma resupinate, pulvinate or nodular

3.3.5.2.3.1. basidioma pulvinate or nodular; sterile surface, if present, rudimentary, sulcate, rimose, grayish to blackish

Phellinus pomaceus

(cm or $\mathrm{dm}$ )

[in or $\mathrm{ft}$ ]

3.3.5.2.3.2. $(\downarrow)$ basidioma pulvinate; sterile surface, if present, hispid, hirsute, reddish brown to dark brown

Inonotus hispidus

(30-50)

[12-20]

3.3.5.2.3.3. $(\downarrow)$ basidioma resupinate to cushion-shaped, sometimes rimose, often fused with other basidiomata; hymenophore cinnamon brown with pores round; margin thin, tomentose, brownish

Pelvinus punctates

(20-40)

[8-16]

3.3.5.2.3.4. basidioma resupinate, nodular; hymenophore cinnamon brown with pores angular; thin but distinct yellowish margin

Innatus hastier

$(8-10)$

[3.2-4] 